UDC 378:37:331.548

DOI: https://doi.org/10.17721/2415-3699.2020.11.05

L. Levytska, PhD (Pedagogical Sciences), Associate Professor,

Taras Shevchenko National University of Kyiv, Kyiv, Ukraine

\title{
VALUABLE ORIENTATIONS IN CULTURE FORMATION OF PEDAGOGICAL INTERACTION TEACHERS - STUDENTS
}

The essence of forming the culture of pedagogical interaction of subjects of educational process of higher education institutions in the system of professional and ethical values is revealed. The main definitions of the process of forming a culture of pedagogical interaction are defined: "subject-object interaction", "subject-subject interaction", "pedagogical interaction", "culture of pedagogical interaction".

The pedagogical interaction is highlighted as a process of cooperation on the basis of mutual assistance and mutual understanding in order to effectively solve educational problems, emotions, attitudes, positions in the educational process.

The culture of pedagogical interaction is outlined as a system of professional and ethical values, which have become internal beliefs of personality, personal qualities, which regulate social and pedagogical relations and are manifested in behavior consistent with the requirements of the professional and ethical code. It is the systemic integrity of interconnected components: axiological, technological, creative and personal. The axiological component represents the culture of pedagogical interaction as a set of pedagogical values. The technology component includes methods and techniques that ensure its effectiveness, as well as the skills and professional interaction and communication. The creative component is manifested in the creation and realization of professional and ethical values and is characterized by autonomy, flexibility and variability of thinking and actions, ability to predict the consequences of social and pedagogical actions, readiness for creative cooperation. The personal component reveals the manifestation of a culture of interaction as a specific way of realizing the essential qualities of the individual.

The content and structure of pedagogical interaction, psychological and pedagogical factors and conditions for forming the culture of pedagogical interaction of the subjects of the educational process of the institution of higher education are revealed.

Keywords: subject-object interaction, subject-subject interaction, pedagogical interaction, pedagogical interaction culture, formation of pedagogical interaction culture, values, students' professional and value orientations.

Formulation of the problem. Education reform is linked to the change in the quality of pedagogical communication, the establishment of equal relations, the co-operation of participants in the learning process.

In higher education the search for new approaches to the training of specialists is continuing, new pedagogical technologies are being introduced, the conditions for higher education of young people are being created, and measures are being taken to integrate it into the world education system. However, the effectiveness of teaching is determined not only by a thoughtful choice of technologies, but also by the teacher's ability to establish and maintain emotional contact with students, to creatively build a system of pedagogically appropriate relations. In order to prepare a highly qualified specialist, it is necessary to radically change the attitude to the student and his / her attitude to learning, which is manifested in his / her active personal position, motivation and purpose of educational and cognitive activity as a result of organizing pedagogical interaction. This actualizes the search and justification of the most effective model, the strategy of interaction of participants of the educational process, which promotes the development of their personalities.

The purpose of the article is to theoretically substantiate the culture of pedagogical interaction in the system of professional and ethical values of the teacher of higher education. According to the purpose, the tasks of the study are defined: 1) to outline the problem of forming a culture of pedagogical interaction and to identify directions that require further scientific research; 2) to reveal the essence of the terms "pedagogical interaction", "culture of pedagogical interaction"; 3) characterize the functional structure of the pedagogical interaction culture.

Analysis of recent research and publications. Various aspects of this problem have been studied by $\mathrm{O}$. O. Abdullin, M. A. Alekseev, A. G. Asmolov, K. Sh. Akhiyarov, G. O. Ball, V. P. Bespalko, O. L. Bogdanova, S. L. Bratchenko, A. S. Gazman, V. V. Davydov, A. J. Kapska, A. V. Kirichuk, N. D. Nikandrov, Y. P. Pravdin, N. V. Chepeleva, and others.

Scientific bases of the organization of higher professional and professional-pedagogical education in Ukraine are developed by I. S. Voloshchuk, N. M. Demyanenko,
M. B. Yevtukh, B. I. Lugovyi, P. G. Luzan, E. V. Luzik, V. K. Mayboroda, V. M. Manko, O. V. Sukhomlinskaya and others.

Historically, the problem of pedagogical interaction has been solved from different positions: from humane attitude to the pupil by the teacher (N. A. Dobrolubov, K. D. Ushinsky, V. O. Sukhomlysky, etc.) to the systematic influence on it in order to form the set qualities. Scientists see it as a special kind of joint activity (X. J. Diimethe), the way of its organization (B. T. Likhachev, Yu. K. Babanskiy), the essential characteristic of the educational process, a special type of relations, the process of activity and personal exchange between the teacher and students, a process that is constantly evolving in space and time (N. F. Radionova) $[2 ; 4 ; 6 ; 7 ; 12]$.

Scientists have investigated individual components of pedagogical interaction: the style of pedagogical leadership (G. A. Aminev, E. I. Rogov, etc.), the style of teacher's behavior (L. M. Zakharov, L. I. Ryumshin, etc.), the type of teacher's attitude to students (M. A. Berezova, Ya. L. Kolominsky, etc.); models of interaction with children (S. L. Bratchenko, V. A. Petrovsky, S. O. Ryabchenko, V. A. Sitarov, etc.) [2; 3; 7; 8; 9].

Also the issues of pedagogical interaction were studied in terms of peculiarities of teachers' personal characteristics, such as self-esteem (M. E. Zelenov), emotional states (O. O. Prokhorov), attitudes and stereotypes (R. A. Samofal), psychological protections (M. I. Buyanov) $[1 ; 2 ; 3 ; 7 ; 12 ; 14]$.

The writings of these scholars focus on the initiating role of the teacher in choosing the model of pedagogical interaction, as well as on the importance of his personal qualities as factors of formation of orientation to the personal model of development. However, the complexity of the implementation of the personal model of pedagogical interaction indicates an insufficient level of exploration of the mechanisms, factors that determine the orientation of teachers to such a model.

Axiological approach to professional training of students, which is expressed in the orientation of vocational education to the formation of future specialists of the system of universal and professional values, which determine the attitude to the world, to themselves, their own activity, is revealed in the scientific works of R. Artyshevsky, I. Beha, 
O. Braslavskaya, M. Yevtukh, I. Ziazun, A. Mishchenko, E. Pochinok, N. Tkachova, A. Yaroshenko, and others.

Presenting main material. In today's context, there is increasing attention to all types of education, which is regarded as the most important factor in social and economic progress. This is because today the main value in society is a person who is able to master new knowledge, ways to solve educational and industrial problems, make non-standard decisions.

In science there are several approaches to knowledge of the objects of reality, training and, in particular, to the organization of vocational training. Their diversity allows them to make an optimal choice, to fully take into account the specific features of a specific participant of educational and cognitive activity, to successfully realize the purpose of this activity. In accordance with current trends in the development of scientific thought, it is advisable and possible to form a culture of pedagogical interaction using a systematic, more active, personality-oriented and competent approach. The above approaches should translate training from the level of formation of a specialist to the level of formation of a competent personality.

Attention should be drawn to the lack of a single interpretation of the concept of "pedagogical interaction" by its pedagogical researchers, its multidimensionality and ambiguity.

Pedagogical interaction is the basis and condition for establishing various relationships in the educational process. Its nature determines the social and student development situation. The interaction, which is based on understanding, empathy, assistance and cooperation, creates a special environment that ensures the satisfaction of basic vital interests. It is possible to create such conditions based on high professionalism of teachers, psychological culture, culture of pedagogical interaction [8].

The culture of pedagogical engagement should be seen as a system of professional and ethical values that have become internal beliefs of the individual. An indispensable condition for its realization is the possession of technology of professional interaction and communication. The characteristics of such a culture are the personal qualities that govern social-pedagogical relationships and behavior consistent with the requirements of the code of ethics [3].

The structure of the pedagogical interaction culture consists of the following components [8]:

- axiological (reveals a culture of pedagogical interaction as a set of pedagogical values);

- technological (ethical ways and methods of activity that ensure its effectiveness, as well as skills and professional interaction and communication);

- creative (manifested in the creation and realization of professional and ethical values and characterized by autonomy, flexibility and variability of thinking and actions, ability to predict the consequences of socio-pedagogical actions, readiness for creative cooperation);

- personal (reveals the manifestation of a culture of interaction as a specific way of realizing the essential qualities of the teacher, which means the needs, abilities, interests, pedagogical experience, measure of social activity of a person).

Emphasis should be placed on the dialectical interrelation of these components, which form a systemic integrity, in which the systemic component is an axiological component.

The culture of pedagogical interaction as an integral property of the individual develops from the lower levels to the upper levels.

The basis of pedagogical interaction is the activity, responsibility and tolerance of all participants in the educational process. Activity as a special mental state, conditioned by innate and acquired needs, develops under the influence of internal and external higher ones. It is realized in pedagogical activity, communication, attitudes of participants and through their attitude to different components of this activity, manifests itself due to the altruistic nature of its content, focus on humanization and harmonization of pedagogical relations, pedagogical means of action, morality of methods.

The effectiveness of forming a culture of pedagogical interaction of the subjects of the educational process in higher education institutions is conditioned by the introduction of a methodology that structurally and functionally provides for the gradual realization of the goals of pedagogical interaction by diagnosing, evaluating and managing this process; is based on theoretical principles that take into account principles, psychological and pedagogical factors and conditions, methods of forming a culture of pedagogical interaction as an integrated personality formation; is ensured by the involvement of teachers and students in cooperation in the educational activity, in which subject-object relations are consistently changed by subject-subject, and reproductive teaching methods are active ways of educational work.

Factors and acquires the qualities of personality traits. In the context of pedagogical interaction, it is about creating such mechanisms that could provide a manifestation of cognitive activity of students, that is, active behavior aimed at initiating independence, perseverance and success in considering and solving creative tasks in the learning process. This concept reflects the interconnection of intellectual, volitional and emotional components. Such activity is formed and manifested in educational and cognitive activity, based on one's own mental experience of the individual and interdependent with his emotionalvolitional orientation, which promotes successful educational activity.

The activity of the individual in learning depends on the formation and realization of cognitive needs, motives and goals of educational activity. It is formed and realized through the motivational sphere of the individual on the basis of the innate need for information, through pedagogical stimulation, through motive-interest, by solving the "externally" posed problems, in the process of creatively solving the independently set tasks. Problems are an important means of activating cognitive activity. The complication of the problem level causes an increase in the intensity of pedagogical interaction $[9 ; 10 ; 11]$.

The downside of activity is responsibility as the ability to anticipate the consequences of each one's actions, choices, objectively analyze and evaluate their actions, and the desire to prevent a possible negative turn of events. Responsibility creates a psychological space for subjectsubject relations, provides appropriate motivational and situational guidance for the unfolding of processes of selfdevelopment and self-realization.

Intrapersonal basis of pedagogical interaction is tolerance as affirmation of multiplicity and diversity of being, recognition of the inevitability of coexistence of differences, dissimilarity, active position of the person against oppression, conscious and value-conscious personal choice, not only tolerance, tolerance, an active effort to understand it, the search for shared values, which creates the opportunity for interaction.

The mechanisms of forming a pedagogical interaction culture should be consistent with the structure of the latter and the functional interconnection of all its components. Formation of educational activity is based on both general 
and specific principles: problems, recognition of the individual interests of the partner, common value of the activity, pedagogical stimulation, optimality, orientation to the future professional activity. Specific principles of teaching, performing a regulatory function in forming a culture of pedagogical interaction, reflect the didactic patterns of this process.

Problem as a means of developing cognitive abilities is the basis for the formation of productive and creative activity, which is characterized by originality of conclusions, nonstandard ways of action, sensitivity to the existence of the problem, the ability to generate new ideas, as well as the availability of basic knowledge, the formation of the ability to perform actions in a certain way, which are formed in reproductive activity.

Encouragement for pedagogical interaction involves the regular transformation of the external factor of influence into internal motivations of the individual to cooperation, the use of subtle incentives for development. Such incentives for the teacher could be participation in scientific-methodological seminars, advanced training courses, use of different sources and methods of evaluation of the teacher's activity, which would provide not only quantitative but also qualitative characteristics, such as the results of surveys of students, graduates, colleagues, etc. A sign of effective stimulation is the transformation of educational action into educational activity, interaction into interactive activity caused by the systematic use of an incentive.

A generalized approach to implementing the principle of optimality is that there are no and there can be no specific rules for any pedagogical situation and uniform recommendations for their settlement. These are possible alternatives and a conscious choice of the most appropriate under certain conditions. This principle applies to all components of the organization of interaction in the educational process and the formation of a culture of pedagogical interaction.

The principle of orientation to the future professional activity implies mastering the knowledge, skills and skills required for the future specialist, from the very first lessons. Thus, educational activities are gradually being transformed into professional ones.

Despite the presence of a certain community of interests, the interaction of the main subjects of social relations is determined by the fundamental differences between their main interests and the presence of contradictions arising from this circumstance. It should be borne in mind that the participants of pedagogical interaction - is the unification of personalities, interconnected individuals with unique subjective experience, a set of mental, cultural traits, since most often people are not inclined to coincide with interpersonal interests, between games. Thinking about contradictions and even entering into the conflict zone and anticipating them, the participants of pedagogical interaction should be guided to search for a unifying, mutual agreement, mutually acceptable conditions for the sake of success. This involves taking into account the interests of all parties, opening up opportunities for frank dialogue, mutual understanding based on reconciliation of basic interests, creating benefits for all.

The principle of shared value of the activity implies that the psychological content of the joint activity is a set of goals, tasks and operations that reflect the main motives of this activity, contribute to meeting the basic needs and consideration of social values of the group members. An important feature of joint activity is a goal that is consistent with the common interest and contributes to the needs of each participant.
It should be noted that the culture of pedagogical interaction combines goals, content of educational material, teaching, teaching, educational microenvironment. These components are closely interconnected and lose their functional orientation outside the system. The mentioned system has a dynamic structure, the system-forming component of which is pedagogical activity.

Thus, VA Kruchek developed a professional-ethical model of the teacher as a carrier of the culture of pedagogical interaction, which includes a block of professional-subject and ethical knowledge, a block of professional-pedagogical skills, a block of knowledge about the professional positions of the teacher and a block of knowledge about the moral and psychological qualities of the teacher. and professional ethics [8-11].

The period of study at a higher education institution is extremely important in the formation of value orientations in student youth: first, the personality develops professional competence and forms a relation to the future profession, and secondly reassesses the values that were inherent in the individual before entering the institution of higher education Thirdly, new values are learned in the process of interaction with other members of the university community. It is necessary to emphasize the importance of higher education institution in the process of value determination of young people and in the process of formation of future specialists, because it serves as a favorable environment not only for the formation of professional skills of the student, but also for his development, as it is the embodiment of society in miniature. Thus, the system of values relates to the specific historical, socio-political, ideological conditions under which it is formed in society as a whole and in each individual $[3 ; 14]$

Educational, educational and developmental functions are inherent in the system of forming the culture of pedagogical interaction, necessitating a number of psychological and pedagogical factors and a number of pedagogical conditions. The main factors that significantly influence the formation of a culture of pedagogical interaction of the subjects of the educational process in higher education institutions include: cognitive abilities of students, content of educational material, teaching methods, educational environment, professional competence of the teacher.

It should be noted that students' cognitive abilities as a peculiar and relatively stable combination of psychological properties is a prerequisite for successful building of pedagogical interaction and formation of its culture. There is a close link between the level of ability development and cognitive activity as the basis of pedagogical engagement. Cognitive abilities exist only in the development that occurs in the course of students' educational activities through exercise. Higher level of development of cognitive abilities determines the speed and soundness of mastering the educational material, the productivity of the process of formation of cognitive needs and motives, the culture of pedagogical interaction.

The educational process, which is oriented on pedagogical interaction, should involve the deployment of the following stages: diagnostics of the actual level of cognitive abilities of students, didactic processing of the content of educational material in accordance with the results of the evaluation of the objective and subjective degree of complexity of educational objects, detection of complications in them; choice of methods depending on the actual and desirable degree of independence of students; communication to students of the goals and the order of the task; creation of conditions for students' readiness for reproductive, productive and creative activity; adaptation of 
cognitive functions to a certain type of educational and cognitive activity; adjusting the methodology based on the assessment of the development of cognitive abilities.

It should be noted that the content of education is the basis for the selection and use of teaching methods that will facilitate pedagogical interaction. Significant is the adherence to the principles of scientificity, relevance, content, optimum level of complexity, structure, systematic, humanization and professional orientation. The positive impact of the content of the educational material on the formation of a culture of pedagogical interaction is provided by: a) purposeful selection and structuring of the content of the educational material in accordance with the cognitive abilities of students; b) applying the system of gradual formation of cognitive skills (reproductive, reproductive-productive, productive, creative); c) preparation of educational-methodical literature with observance of requirements for content selection, its differentiation, structure, construction of methodological apparatus; d) constant concentration of students' attention on mastering the content of educational material. It is important that in the process of selection and structuring of the educational material, it is necessary to take into account the objective didactic conditions that determine the complexity of the objects for study.

It is appropriate to state that the formation of the content of educational material should provide diagnostics of the actual level of cognitive abilities of students, the formation of cognitive and students' skills starting from reproductive type skills, assessing the objective degree of complexity of educational objects, determining the cognitive skills required for conscious awareness, analysis for the presence of complicating features, determination of the discrepancy between the students' abilities and the required level of educational and cognitive iyalnosti, ie subjective complexity of the educational facility. Cognitive complications stimulate student activity in the case of matching their potential capabilities, ensuring the optimal balance of opportunities and the nature of cognitive activity that they have to show. Comparison of the actual level of development of cognitive activity with the necessary allows the teacher to assess the complexity of the content and the real possibilities of its assimilation not only intuitively but also scientifically.

The formation of the interactive position of the participants of the educational process is influenced by the orientation of the educational environment and, in particular, such conditions of its functioning as the humanistic nature of educational influence in the environment, openness and dynamism, accentuation of the communicative component in the content of education, constant diagnostic and correction pedagogical influence on this educational environment. The educational environment is a set of objective external conditions, factors, social objects necessary for the successful functioning of education, the system of influences and conditions of personality formation, as well as opportunities for its development in the social and spatial environment.

The external factors of the educational environment are the socio-cultural reality in which the educational institution operates. The educational environment as a sociocultural phenomenon is a set of conditions, specially created by the state and society, necessary for a person to receive education in the course of his life, a zone of interaction of educational systems, their elements, subjects of educational processes. An internal factor in the educational environment is the system that generates:

- organization of educational process, logic of educational and cognitive activity;
- professionalism of teachers, teachers and students' creative activity;

- communication strategy and tactics in the educational process.

Creating a favorable culture of pedagogical interaction of the educational environment involves providing conditions for social adaptation and integration of participants in the educational process, creative self-realization of each in the accessible spheres of life, psychological support for members of the student group, teachers, organization of coordination-mediating assistance and the avoidance of authoritarianism and formalism in them.

Positive influence on the formation of a culture of pedagogical interaction is possible provided the functioning of interpersonal space, in which each person feels emotionally comfortable and stable in terms of selfrealization, which allows to provide a choice of values, life meaning, specific microenvironment of activity, ways.

Pedagogical conditions for forming a culture of pedagogical interaction are: reorientation of educational and professional communication as a creative activity, realization of the subject-subjective nature of pedagogical communication, accuracy, expressiveness and imagery of speech, activation of emotional sphere, constant attention to development application of methods of assessing the level of pedagogical interaction culture. These conditions contribute to the active involvement of all participants of the pedagogical process in the discussion and implementation of educational activities, their research position, tolerant decision-making, maintaining constant feedback, partnership communication.

The culture of pedagogical interaction is formed and manifested in educational and cognitive activity, which has the appropriate structure (stimulating substructure - need, motive, object, purpose; instrumental - conditions, means, composition; controlling - control, evaluation, product). It highlights the stages of need development, motivational search, goal formation, subject transformation, and control and evaluation. This structure is a benchmark for building a methodology for forming a culture of pedagogical interaction.

The process of forming a culture of pedagogical interaction with the help of educational tasks involves formulating the purpose of educational work and its acceptance by students, preparation of basic educational tasks, development of elements of their complexity, grouping by level of complexity, diagnosis of cognitive opportunities, selection and solution of educational task of the appropriate type. Further assessment of the student's actions is accompanied by self-control. To create a developmental situation, tasks of increased complexity, corresponding to the area of immediate development, are consulted. Acceptance and resolution of a difficult task by the student provides the result in the form of cognitive development.

The culture of pedagogical interaction is formed by demonstrating the necessity of mastering the educational material for future professional activity, preliminary acquaintance of students with the structural and logical scheme of discipline study, purposeful use of problem learning methods, teaching potential of the game, teaching aids, learning activities, full implementation of the functions of control of learning outcomes, application of varieties evyh tests, aggregate testing methods and assessment.

It should be noted about the significant potential of forming a culture of pedagogical interaction in the lecture form of teaching, including problematic lectures, two lectures, visualization lectures, lectures with planned mistakes; seminars in the form of a classic seminar, discussion seminar, round table, expert group meeting, 
forum, symposium; practical training in the form of educational business game, training in the analysis of industrial situations; training sessions.

Successful formation of a pedagogical interaction culture is possible under the condition of systematic organization of testing and assessment of knowledge, skills and skills of future specialists, in which at all stages of control different types of it are realized through a set of methods and forms aimed at determining the quality of mastering the educational material, the degree of conformity of educational achievements of students. the goals and objectives of the discipline, the ability to master knowledge independently.

Controls and complex evaluation of teaching and pedagogical activity of a teacher based on formal and informal rating among students, opinion of graduates, members of the Student Council, rating among colleagues, assessment of the leader, content of educational disciplines, participation, conferences, student performance reports, levels of residual knowledge, self-esteem. The organizational and pedagogical conditions for exercising such control are a clear setting of tasks for a certain period of work, systematic control of the fulfillment of professional duties by the administration, complexity of the evaluation of pedagogical activity, dependence of the amount of remuneration and empowerment of scientific and pedagogical staff on the evaluation of work.

Thus, the theoretical analysis of this problem has led to the conclusion that pedagogical science and practice have accumulated a great deal of experience in the organization of pedagogical communication and formation of communicative competence of teachers. However, the current state of organization of training of specialists in higher education institutions does not meet current requirements and needs; insufficient consideration of the impact of socio-political changes that have taken place in Ukraine, slowness of transition from established models of specialist training to more advanced ones, low motivation to master professional knowledge, outflow of qualified scientific-pedagogical personnel into commercial enterprises and organizations, as well as abroad which leads to the risk of higher education institutions being replenished by incompetent or poorly trained specialists.

Pedagogical interaction should be considered as a process of cooperation on the basis of mutual assistance and understanding in order to effectively solve educational problems, purposeful exchange and enrichment with the meaning of activity, experience, emotions, attitudes, positions in the educational process. It is characterized by activity, awareness, goal-setting, systematic, multidimensionality. Pedagogical interaction as the basis and condition for establishing relationships in the pedagogical process creates a special environment for meeting the vital needs of its participants, professional growth and, thus, determines the social situation of development.

The culture of pedagogical interaction is a system of professional and ethical values that have become internal beliefs of personality, personal qualities, which regulate social and pedagogical relations and are manifested in behavior consistent with the requirements of the professional and ethical code. It is the systemic integrity of the dialectically interrelated axiological, technological, creative and personal components. The axiological component represents the culture of pedagogical interaction as a set of pedagogical values. The technology component includes methods and techniques that ensure its effectiveness, as well as the skills and professional interaction and communication. The creative component is manifested in the creation and realization of professional and ethical values and is characterized by autonomy, flexibility and variability of thinking and actions, ability to predict the consequences of social and pedagogical actions, readiness for creative cooperation. The personal component reveals the manifestation of a culture of interaction as a specific way of realizing the essential qualities of the individual.

Conclusions and perspectives of further research. Summarizing the above, it should be noted that the value orientations of the individual are defined as accepted and conscious values that determine her choice of a certain type of behavior, act, way of life. In the personality structure, value orientations serve as the foundation on which the line of professional behavior is built. At the stage of the primary choice of profession, professional values, defined by the personality as the most significant, begin to emerge. In the process of professional development, values are tested, supplemented, acquired more and more personal value, and the individual identifies himself / herself as a representative of this profession.

The study does not exhaust all the search and research aspects of the problem. Further analysis and study require aspects of the application of new interactive technologies in the educational process of the university to form the value sphere of future professionals and the culture of their pedagogical interaction.

References

1. Artimonova T. Osnovni dukhovni priorytety student.s'koyi molodi: napryamy transformatsiy / T. Artimonova // Vyshcha shkola Ukrayiny. - 2008. № 1. $-\mathrm{S}$. 72-75.

2. Bekh I. D. Vykhovannia osobystosti: [navch. posibnyk] / I.D.Bekh. Kyiv.: Lybid', 2008. - 848 s.

3. Hordieieva K. S. Profesiini tsinnosti v systemi sotsial'no-pedahohichnoi roboty: psykholohichnyi aspekt / K. S. Hordieieva // Humanizatsiia navchal'no-vykhovnoho protsesu: zbirnyk naukovykh prats' / [za zah. red. prof. V. I. Sypchenka]. - Slov'ians'k: DDPU, 2014. - Vypusk LXVIII. - Ch. I. - S. 182-188.

4. Entsyklopediia osvity [entsyklopediia] / V.H.Kremen'. - Kyiv: Yurinkom Inter, 2008. - $1040 \mathrm{~s}$

5. Etyka: [navch posibnyk] / V O.Lozovoi, M.I.Panov, O.A.Stasevs'ka ta in - K: Yurinkom Inter, 2002. - S. 103.

6. Zhelanova V.V. Teoretyko-metodolohichni aspekty problemy tsinnostey osobystosti / V.V. Zhelanova, A.V. Petsanova // Visnyk Luhans'koho natsional'noho pedahohichnoho universytetu im. T.Shevchenka (pedahohichni nauky). 2008. - № 7. - S. 114-119.

7. Kalashnikova L.U. Umovy formuvannia sotsial'noi pozytsii studenta / L.U.Kalashnikova // Pedahohika ta psykholohiia. 2014. - Vyp. 45. - S. 125-134.

8. Kruchek V. A. Formuvannya kul'tury pedahohichnoyi vzayemodiyi: monohrafiya / V. A. Kruchek. - K.: NAKKKiM, 2012. - 408 s.

9. Kruchek V. A. Doslidzhennya sformovanosti komunikatyvnykh umin' studentiv vyshchykh zakladiv osvity / V. A. Kruchek // Nauk. chasop. Nats. ped. untu im. M. P. Drahomanova: zb. nauk. pr. K.: NPU im. M. P. Drahomanova, 2007. № 17 (41). CH. 1. S.

10. Kruchek V. A. Tolerantnist' yak osnova pedahohichnoyi vzayemodiyi / V. A. Kruchek // Nauk, chasop. Nats. ped. un-tu im. M. P. Drahomanova: zb. nauk. pr. - K.: NPU im. M. P. Drahomanova, 2007. Vyp. 5. CH. 1. S. 310-314.

11. Kruchek V. A. Struktura kul'tury pedahohichnoyi vzayemodiyi V. A. Kruchek // Visn. Kyyiv. nats. un-tu im. Tarasa Shevchenka. K.: [b.v.], 2009. № 3. - S. 138-146.

12. Solovei M.I., Kudina V.V., Spitsyn le.S. Profesiino-pedahohichna pidhotovka maibutn'oho vchytelia $v$ kredytno-modul'nii systemi orhanizatsii navchannia: [navchal'nyi posibnyk] / M.I.Solovei, V.V.Kudina, le.S.Spitsyn. Kyiv: Lenvit, 2013. - 414 s. - S. 148.

13. Sukhomlyns'ka O. V. Tsinnosti u vykhovanni molodi ta ditey: stan rozroblennya problemy. Pedahohika i psykholohiya. 1997. № 1. - S. 105-111.

14. Tsinnosti osvity i vykhovannia: [navch. posibnyk] / O.V.Sukhomlynska. - Kyiv, 1997.

Список використаних джерел

1. Артімонова Т. Основні духовні пріоритети студентської молоді: напрями трансформацій / Т. Артімонова // Вища школа України. - 2008. № 1 - - С. $72-75$.

2. Бех І. Д. Виховання особистості : навч. посібник / І.Д.Бех. - К.: Либідь, 2008. -848 с.

3. Гордєєва К. С. Професійні цінності в системі соціально-педагогічно роботи: психологічний аспект / К. С. Гордєєва // Гуманізація навчальновиховного процесу: збірник наукових праць / за заг. ред. проф. В. І. Сипченка. - Слов'янськ: ДДПУ, 2014. - Випуск LXVIII. - Ч. І. - С. 182-188.

4. Енциклопедія освіти [енциклопедія] / В.Г.Кремень. - К.: Юрінком Інтер, 2008. - 1040 c. 
5. Етика : навч. посібник / В.О.Лозовой, М.І.Панов, О.А.Стасевська та ін. - К.: Юрінком Інтер, 2002. - 224 с. - С. 103.

6. Желанова В.В. Теоретико-методологічні аспекти проблеми цінностей особистості / В.В. Желанова, А.В. Пецанова // Вісник Луганського національного педагогічного університету ім. Т.Шевченка (педагогічні науки). - 2008. - № 7. - С. 114-119.

7. Калашнікова Л.Ю. Умови формування соціальної позиції студента / л.Ю.Калашнікова // Педагогіка та психологія. - 2014. - Вип. 45. - С. 125-134.

8. Кручек В. А. Формування культури педагогічної взаємодії: монографія / В. А. Кручек. - К.: НАКККіМ, 2012. - 408 с.

9. Кручек В. А. Дослідження сформованості комунікативних умінь студентів вищих закладів освіти / В. А. Кручек // Наук. часоп. Нац. пед. ун-ту ім. М. П. Драгоманова : зб. наук. пр. - 2007. - № 17 (41), Ч. 1. - С. 196-200.
10. Кручек В. А. Толерантність як основа педагогічної взаємодії / В. А. Кручек // Наук часоп. Нац. пед. ун-ту ім. М. П. Драгоманова : зб. наук. пр. - 2007. - Вип. 5, Ч. 1. - С. 310-314.

11. Кручек В. А. Структура культури педагогічної взаємодії / В. А. Кручек // Вісн. Київ. нац. ун-ту ім. Тараса Шевченка. - 2009. - № 3. - С. 138-146.

12. Соловей М.І., Кудіна В.В., Спіцин Є.С. Професійно-педагогічна підготовка майбутнього вчителя в кредитно-модульній системі організації навчання : навч. посіб. / М.І.Соловей, В.В.Кудіна, Є.С.Спіцин. - К.: Ленвіт, 2013. $-414 \mathrm{c}$.

13. Сухомлинська О. В. Цінності у вихованні молоді та дітей: стан розроблення проблеми. Педагогіка і психологія. - 1997. - № 1. - С. 105-111.

14. Цінності освіти та виховання : наук.-метод. зб. / За заг. ред. Сухомлинської О.В. - К., 1997. - 224 с.

Л. Левицька, канд. пед. наук, доц.

Київський національний університет імені Тараса Шевченка, Київ

\section{ЦІННІСНІ ОРІЄНТАЦІЇ У ФОРМУВАННІ КУЛЬТУРИ ПЕДАГОГІЧНОЇ ВЗАЄМОДІЇ ВИКЛАДАЧ - СТУДЕНТ}

Розкрито сутність формування культури педагогічної взаємодії суб'єктів освітнього процесу закладів вищої освіти в системі професійно-етичних чінностей. Визначено основні дефініції прочесу формування культури педагогічної взаємодії: "суб'єкт-об'єктна взаємодія", "суб'єкт-суб'єктна взаємодія", "педагогічна взаємодія", "культура педагогічної взаємодії".

Висвітлюється педагогічна взаємодія як процес співробітництва на основі взаємодопомоги та взаєморозуміння з метою ефективного вирішення освітніх завдань, емоціями, установками, позиціями в освітньому процесі.

Окреслено культуру педагогічної взаємодії як систему професійно-етичних цінностей, що стали внутрішніми переконаннями особистості, особистісних якостей, які регулюють соціально-педагогічні відносини та проявляються у поведінці, узгодженій з вимогами професійно-етичного кодексу. Вона є системною цілісністю взаємопов'язананих компонентів: аксіологічного, технологічного, творчого та особистісного. Аксіологічний компонент подає культуру педагогічної взаємодії як сукупність педагогічних цінностей. Технологічний компонент включає способи і прийоми діяльності, що забезпечують її ефективність, а також уміння і навички професійної взаємодії і спілкування. Творчий компонент виявляється у створенні й реалізації професійно-етичних цінностей та характеризується самостійністю, гнучкістю і варіативністю мислення та дій, умінням прогнозувати наслідки соціально-педагогічних дій, готовністю до творчої співпраці. Особистісний компонент розкриває прояв культури взаємодії як специфічного способу реалізації сутнісних якостей особистості.

Розкрито зміст і структуру педагогічної взаємодії, психолого-педагогічні фактори і умови формування культури педагогічної взаємодії суб'єктів освітнього процесу закладу вищої освіти.

Ключові слова: суб'єкт-об'єктна взаємодія, суб'єкт-суб'єктна взаємодія, педагогічна взаємодія, культура педагогічної взаємодії, формування культури педагогічної взаємодії, цінності, професійно-ціннісні орієнтації студентів.

UDC 378:331.361

DOI: https://doi.org/10.17721/2415-3699.2020.11.06

A. Marushkevych, Professor, Doctor of Pedagogical Sciences, I. Mariuts, PhD, Assistant Professor, Taras Shevchenko National University of Kyiv, Kyiv

\section{PROFESSIONAL PEDAgOGICAL TRAINING OF SCIENTIFIC SUBSTANTIATION OF THE UKRAINIAN SCHOLARS}

The article presents the approaches of Ukrainian scientists to the professional training of future pedagogues of higher educational institution. The main positions of the state documents on this issue are analyzed. The basic professional knowledges, skills and competences, what a modern lecturer of a higher education institution should possess are described. Requirements for theoretical preparation of the future lecturer, the level of his/her professional knowledge, general professional skills outlined. Considerable attention paid to peculiarities of the future lecturer's personality formation. It indicates professionally significant qualities of the personality of the future lecturer, the functional manifestations of qualities of his/her personality, formation of professional and creative competences. General theoretical problems of the preparation of future lecturers in higher education institutions, the development of students' readiness for pedagogical activity, and scientific research work disclosed.

Keywords: Lecturer, professional knowledge, professional training of future pedagogues, skills and competences.

Formulation of the problem. Requirements to the development of national education sector raised under conditions of integration of Ukraine to the European Educational Area. These peaks contradictions in the present-day system of higher education between the goal of forming a qualified specialist and the means to achieve it. Contradictions between the task of providing his/her professional and personal development on the basis of the humanistic pedagogy and directive methods of training, between the large scale character of teacher's training and the individual character of pedagogical activity of each scientific-pedagogical worker. Thus, there is no doubts that the designation of long-term strategies for further improving the future teachers training a university is necessary.

Based on analysis of the national documents on education (Constitution of Ukraine, Laws of Ukraine "On Education", "On General Secondary Education", "On Extracurricular
Education", "On Higher Education", "The Concept of General Secondary School", National Doctrine of Education Development in Ukraine, the National Strategy for the Education Development in Ukraine until 2021), we can conclude that the state provides equal access to education, its development in state and municipal educational institutions in any of forms. It supports the preparation of high qualification specialists, including educators, professors of higher education institutions. In this context, we find important to modernize the process of teachers training in Ukraine, their professional development, update approaches to implementation of their abilities. The productivity of teacher depends on his/her knowledge of discipline and methods of teaching, on his/her ability to assess the results achieved, on the level of pedagogical skills and others.

Analysis of recent researches and publications. General issues of professional-pedagogical training of future 